\title{
Climatic changes and collapses in Maya history
}

Tim Beach', S. Luzzadder-Beach', N. Dunning ${ }^{2}$ and D. Cook ${ }^{3}$

\section{Archaeology and paleoclimatology provide insights into the vagaries of Maya history and climate. Although millions of Maya persist today, three main historical declines coincide with drought records. These are important examples of humanity's complex interactions with drought and environmental change.}

The idea that the Classic Maya of Central America "collapsed" dates back to at least the 19th century (Luzzadder-Beach et al. 2012). Explorers like Stephens and Catherwood, in the 1840s, documented many ancient Maya cities in stages of decay. These writings and pictures of temple ruins enshrouded by tropical forest provided imagery of a lost Maya world. Both "collapses" (profound reductions in population or reductions in social complexity) and "declines" (depopulations) occurred over Maya history. Archaeologists have long studied both, and the roles that climate may have played has attracted worldwide attention, but how this great culture persisted is even more interesting (Beach et al. 2015). Although there is convincing paleoclimatic evidence for droughts during several Maya periods, the archaeological evidence for collapse during any of these periods remains coincidental.

The vagaries of Maya cities varied across time and space. In the northern Yucatán, the city of Mayapán collapsed around 1440 AD and Chichén Itzá declined around 1250 AD. The Maya heartland cities from Uxmal southward to Copán flourished into the 9th and 10th centuries AD (Fig. 1). El Mirador and other early urban centers collapsed much earlier, around 150 AD. These lines of evidence suggest three main cessation periods: The Late Preclassic (300 BC-250 AD) or just after, the Late and Terminal Classic (700-1000 AD), and the Early Post Classic (1000-1100 AD). Several paleoclimate records indicate drier conditions either during or near these three periods of social and cultural upheaval (Fig. 2), and some studies linked the Middle Classic hiatus, a period of stagnation (ca. 550 AD) around Tikal, to drought (Beach et al. 2015).

But scholars debate when collapse actually occurred or if any specific collapse occurred because millions of Mayan language speakers still exist. One view is that the collapse occurred mainly after European conquest and subsequent indigenous population declines, caused by European diseases, forced religious and social conversions, and cultural truncation. One vivid example of this was Europeans burning Maya books, terminating a millennia-old glyph-based language.

A key region of Maya lowlands collapse was the Elevated Interior Region (EIR), which lies prone to water stress far above perennial water sources. Here the Maya built various forms of water storage such as the many reservoirs at the great cities of Tikal and Caracol (Beach et al. 2015). The Maya tended to overbuild reservoirs to withstand rainfall variability, but these systems may not have been survivable under severe droughts. Indeed, the EIR was an appealing place in the wetter Preclassic and drought remained manageable even in the drier Late Preclassic, but later droughts may have proved insurmountable (Fig. 2).

The Maya Collapse literature includes a legion of causes, such as droughts, soil deterioration, hurricanes, epidemics, and seismicity, as well as social upheavals in religion, warfare, and trade routes (Beach et al. 2015). Climate change could have led to crop failures, famine and refugees. These in turn could have led to other environmental or social changes, like the Maya rejection of rulers, warfare or changes in trade routes away from the EIR, which could never regenerate in this drought-prone land (Turner and Sabloff 2012).
Like other tropical climates, the Maya lowlands has pronounced wet and dry seasons. The May through November wet season arises from atmospheric instability of the intertropical convergence zone (ITCZ) and the December to May dry season is caused by air stability from the subtropical high pressure (STHP). Rainfall comes from convection and convergence systems of all scales and varies both inter-annually and geographically, ranging from $500 \mathrm{~mm}$ per annum in northwest Yucatán to above 3000 $\mathrm{mm}$ in the southern mountains (Fig. 1).

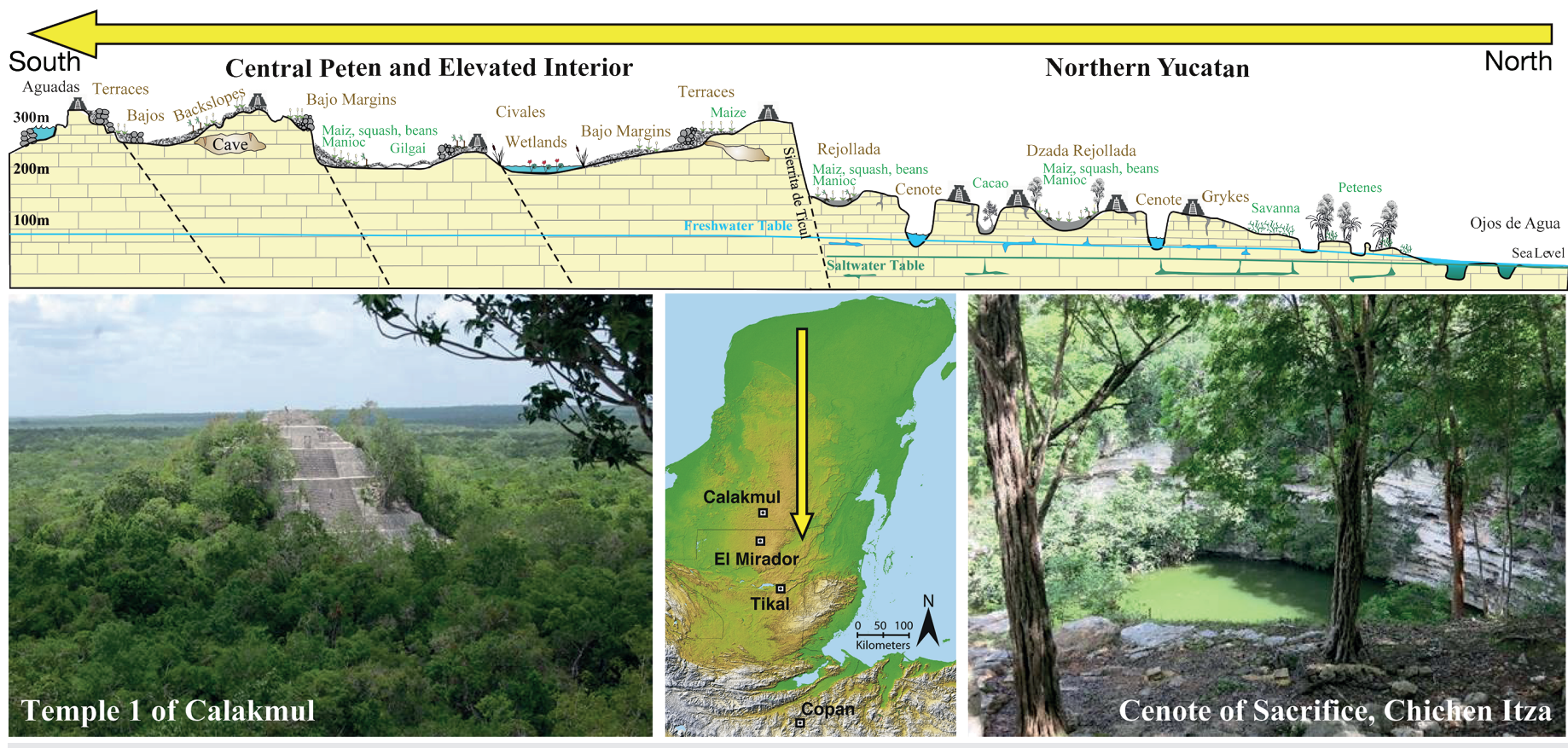

Figure 1: Map and landscape diagram of the Yucatán Peninsula in Central America showing the relationship between the Maya lowlands and the more elevated interior. 


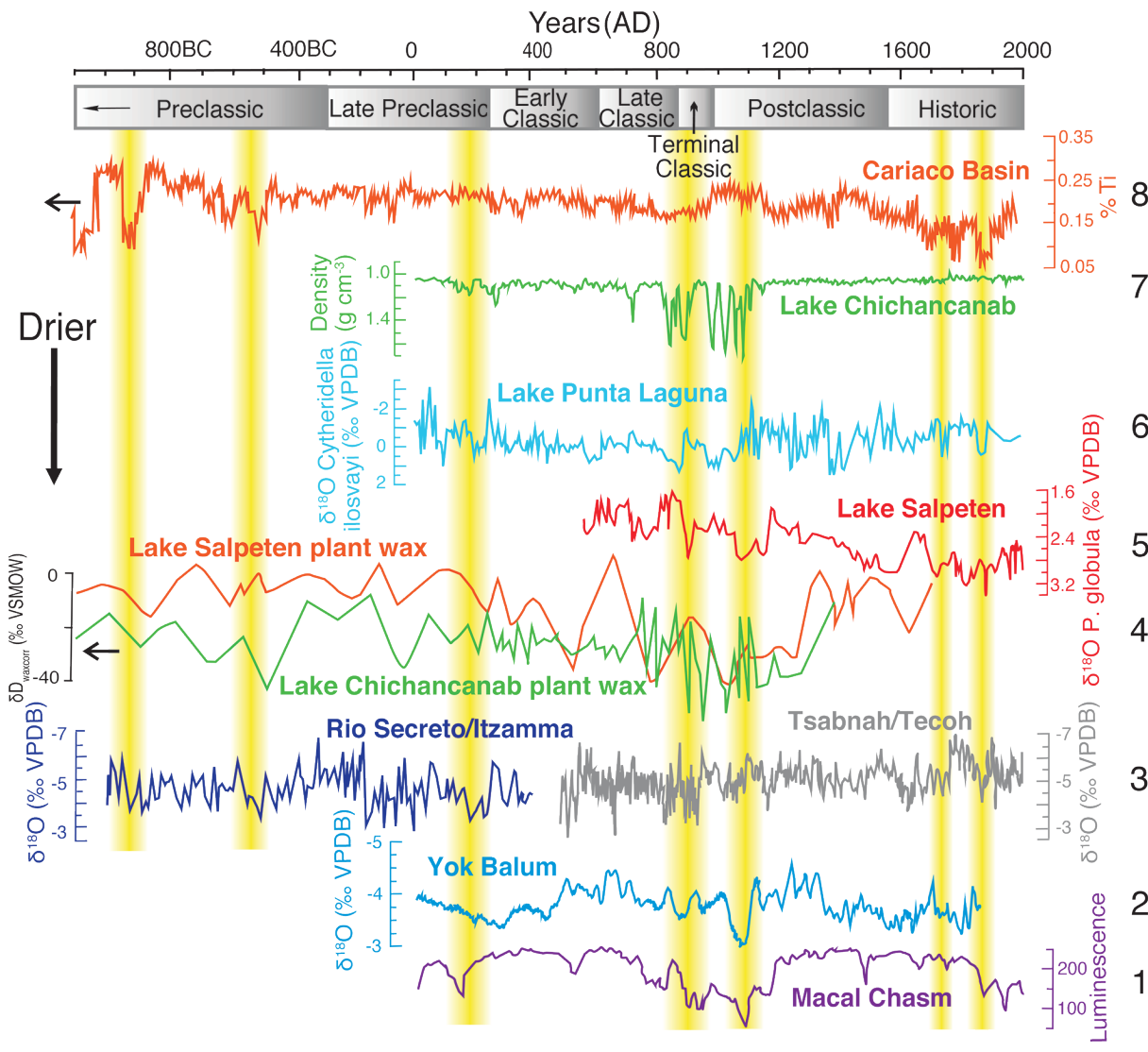

Figure 2: Climate proxy records overview for the Maya lowlands with droughts highlighted in yellow (redrafted after Luzzadder-Beach et al. 2016). See text for references to numbers in the right-hand column.

The Maya lowland's climate change record derives from cave speleothems, and lake and marine sediments (Fig. 2). Speleothem records are especially important because of their finer chronology that can overlap with instrumental records. Speleothems that can accurately fit instrumental records provide confidence for hindcasting past climate and overlapping the many but coarser-resolved lake records.

These records indicate three key arid periods that coincide with declines of Maya polities. The earliest such drought occurs in the last century of the Late Preclassic (150-250 AD), and three northern Yucatán and southern Belize speleothem records in dicate drought at or just after this time (Fig. 2.1, 2.2, 2.3). Sediments from the northern Yucatán lakes and the Cariaco Basin provide overlapping evidence (Figure 2.4, 2.6, 2.7, 2.8). The archaeological evidence includes the collapse of the giant site of El Mirador and allied centers, as well as the iconic Preclassic site of San Bartolo and coastal site of Cerros (Fig. 1), but elsewhere there were mainly temporary declines and social upheavals (Dunning et al. 2012; lannone 2014). A speleothem record from the heart of the collapse zone in Guatemala's Petén may help us frame this drought.

The Middle Classic hiatus (ca. 550 AD) provides a less-convincing case. Studies from around the world indicate a global cooling event (Büntgen et al. 2016) and at least two large volcanic eruptions (one possibly from Mesoamerica) from 536-540 AD (Sigl et al. 2015). Some studies link drought and cultural declines at this time, but most link the hiatus with war mainly around the Tikal region (lannone 2014).

The Terminal Classic saw the decline of many more cities, ranging spatially from Yucatán to Honduras and temporally from about 700 to 900 AD (Webster 2002). A few cities, especially coastal plain or riverine ones like Lamanai, flourished longer (Beach et al. 2015). The climatic evidence also has a wide geographic range from northern Yucatán to the Cariaco Basin, though some records are more equivocal (Fig. 2). One key climate archive has been Laguna Chichancanab (Fig. 2.4, 2.7; Hodell et al. 1995), where the scientific study of the Terminal Classic drought began (Beach 2016). Several climate records also indicate droughts in the Early Post Classic (Fig. 2.1, $2.2,2.5,2.7)$.

Some research also suggests the LateTerminal Classic drought period had more extreme events like hurricanes, which could have exacerbated drought impacts and masked their severity (Frappier 2013). Indeed, the Maya dealt with overlapping hazards in the Late- and Terminal Classic. Hurricane runoff can damage soils and trees and lead to an increased risk of forest fire from fuel build-up. Sea-level rise affected many coasts, and the lack of large coastal Maya cities suggests coastal hazards played some role in ancient Maya urban geography (Dunning et al. 2012).

The Terminal and Postclassic droughts would have been challenging to any civilization, and especially so in the Maya heartland with its dearth of permanent water sources. Some studies suggest that the Maya here started building reservoirs in the Late Preclassic and Early Classic coincident with or after drought, which may have offered stability for centuries. But sedimentation reduced storage capacity so that by the intense droughts of the Late to Post Classic water storage (resiliency) had 7 diminished (Beach et al. 2015). Also, the large-scale abandonment of the Terminal Classic may have reset Maya trade and production geography, which the Early Postclassic drought reinforced. More droughts occurred later in the Little Ice Age and the long trend of Late Holocene drying (Wanner et al. 2008) may have made the EIR 5 unattractive. Thus, the EIR, erstwhile center of Maya Civilization, lost its appeal by the Postclassic. Thereafter, the Maya chose to

4 live, trade and farm near perennial water sources along the Maya lowlands' margins until European conquest.

3 The 21st century is bringing new climate challenges to the Maya lowlands. The IPCC anticipates that temperatures will rise and precipitation fall, increasing water stress (Margrin et al. 2014). We still need more research that can pair climate histories with archaeology to better understand the role of climate in Maya history. New paleoclimate research from this data-poor region can complement and extend modern records of climate and improve models of future climate change. Likewise, archaeological research that can identify and date features that signify adaptation to droughts, like dams, canals and water harvesting, may help us identify critical thresholds in social responses to water stress.

\section{AFFILIATIONS}

'Geography and the Environment, The University of Texas at Austin, USA

${ }^{2}$ Geography, The University of Cincinnati, USA ${ }^{3}$ School of Arts, Australian Catholic University, Brisbane, Australia

\section{CONTACT}

Tim Beach: beacht@austin.utexas.edu

\section{REFERENCES}

Beach T et al. (2015) Quat Sci Rev 124: 1-30 Beach T (2016) Global Planet Change 138: 1-2 Büntgen U et al. (2016) Nat Geosci 9: 231-236

\section{Dunning N et al. (2012) PNAS 109: 3652-3657}

Frappier AB (2013) Geochem Geophys Geosyst 14 3632-3647

Hodell DA et al. (1995) Nature 375: 391-394

lannone G (2014) The Great Maya Droughts in Cultural Context: Case Studies in Resilience and Vulnerability. University Press of Colorado, 448 pp

Luzzadder-Beach S et al. (2012) PNAS 109: 3646-3651 Luzzadder-Beach S et al. (2016) Antiquity 90: 426-442 Magrin GO et al. (2014) In: Barros VR et al. (Eds) Climate Change 2014. Part B: Regional Aspects. Cambridge University Press, 1499-1566 Sigl M et al. (2015) Nature 523: 543-549 Turner BL, Sabloff JA (2012) PNAS 109: 13908-13914 Wanner Het al. (2009) Quat Sci Rev 27: 1791-1828

Webster DL (2002) The Fall of the Ancient Maya: Solving the Mystery of the Maya Collapse. Thames \& Hudson, $368 \mathrm{pp}$ 